\title{
Technical Paper \\ Special articles: Biomass \\ 特集：バイオマス \\ Elemental Speciation Analysis of Iron Compounds in Carbonized Biomass and Its Thermal Behavior by Oxidation Reaction
}

\author{
Atsushi UEDA ${ }^{*}{ }^{\dagger}$, Hideki KAWAI ${ }^{* 2}$, Hiroshi NOGAMI ${ }^{* 3}$, Satoru HIRA ${ }^{* 4}$, Kenji SuZUKI ${ }^{* 4}$, and Ryuji TAKEDA ${ }^{*}$ \\ (Received April 2, 2018)
}

\author{
バイオマス炭化物の鉄化合物形態解析と酸化反応による熱挙動 \\ 上田厚志 $1^{\dagger}$ ，河合秀樹 ${ }^{2}$, 埜上 洋*3，日良 聡 $* 4$, 鈴木健治 $* 4$, 武田龍二*4
}

\begin{abstract}
Waste biomass may contain artificial compounds added during the intermediate treatment process of biomass, as well as natural inorganic matter and compounds discharged by human activity. Carbonized biomass produced for the purpose of fuel utilization for example, may affect self-heating characteristics depending on the compound added. In this study, in order to evaluate the effect on self-heating characteristics by iron compounds produced by carbonization, poly ferric sulfate was selected as a compound to be added, and elemental speciation of iron compounds and thermal behavior by oxidation reaction of carbonized biomass were analyzed. As a result, it was found that carbonized biomass containing poly ferric sulfate may have decreased self-heating characteristics by retaining under air atmosphere for several days. From elemental speciation analysis of iron compounds, it was confirmed that hydrates of $\mathrm{FeSO}_{4}$ exists in carbonized biomass immediately after production and become $\mathrm{Fe}(\mathrm{OH}) \mathrm{SO}_{4}$ after oxidation reaction. As a result of analysis of thermal behavior of carbonized biomass, it was found that heating value due to oxidation reaction tended to increase according to the amount of poly ferric sulfate. When the amount of poly ferric sulfate is large, it could greatly affect heating value of the whole of carbonized biomass.
\end{abstract}

Key Words

Biomass, Carbonization, Poly ferric sulfate, Oxidation

廃棄物系のバイオマスには，天然由来の無機物や人間活動に伴って排出される化合物の他，バイオマスの中間処理工程 の中で添加される人工的な化合物が含まれる場合がある。燃料利用等を目的にバイオマスから炭化物を製造する場合, 添 加される化合物によっては, 自己発熱性に影響を与える可能性がある。そこで本研究では, 炭化処理にて生成された鉄化 合物による自己発熱性への影響を評価するため, 添加する化合物としてポリ硫酸第二鉄を選定し, 鉄化合物の形態解析 と酸化反応による熱挙動について確認を行った。その結果，ポリ硫酸第二鉄を含むバイオマスから製造された炭化物は, 数日間空気䨌囲気下で保持することにより，もとのバイオマスより自己発熱性が抑制される可能性があることがわかった。 鉄化合物の形態解析の結果によると, 製造直後の炭化物には, $\mathrm{FeSO}_{4}$ の水和物が存在し，それを酸化させることにより $\mathrm{Fe}(\mathrm{OH}) \mathrm{SO}_{4}$ となることが確認された。また，炭化物の発熱挙動を確認した結果，添加するポリ硫酸第二鉄の量に応じて酸 化反応による発熱量が増す傾向が認められた。ポリ硫酸第二鉄の添加量が多い場合には, 炭化物全体の発熱に大きな影 響を与えることが示唆された。

キーワード

バイオマス，炭化，ポリ硫酸第二鉄，酸化

※1 Environmental Business Division, TSUKISHIMA KIKAI CO., LTD.

3-5-1, Harumi, Chuo-Ku, Tokyo, 104-0053, Japan

※2 Division of Production Systems Engineering, Muroran Institute of Technology

27-1, Mizumoto-cho, Muroran, 050-8585, Japan

※3 Institute of Multidisciplinary Research for Advanced Materials, Tohoku University

2-1-1 Katahira Aoba-ku, Sendai, 980-8577, Japan

※ Development Division, Laboratory,

TSUKISHIMA KIKAI CO., LTD.

1-12, Shiohama, Ichikawa, Chiba Prefecture, Japan

$\dagger$ Corresponding author: atsu_ueda@tsk-g.co.jp

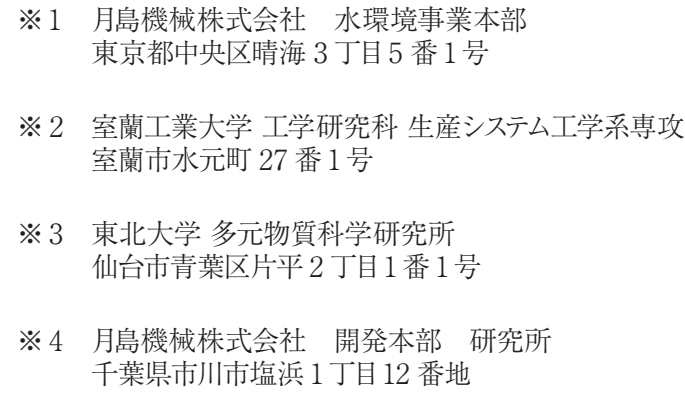

$※ 1$ 月島機械株式会社 水環境事業本部 東京都中央区晴海 3 丁目 5 番 1 号

※2 室蘭工業大学 工学研究科 生産システム工学系専攻 室蘭市水元町 27 番 1 号

$※ 3$ 東北大学 多元物質科学研究所 仙台市青葉区片平 2 丁目 1 番 1 号

$※ 4$ 月島機械株式会社 開発本部 研究所 千葉県市川市塩浜 1 丁目 12 番地 


\section{1. 緒 言}

バイオマスは，太陽エネルギーと生物活動がある限り持続 的に再生可能な資源であり，エネルギー資源のそしい我が国 にとって貴重なエネルギー源となっている。また，バイオマ スはカーボンニュートラルという特性を持っていることから, 化石燃料の代替燃料として利用することで温室効果ガスの 削減にも寄与する。こうした利点を持つバイオマスの活用を 推進するため, 2009 年 6 月に制定されたバイオマス活用推進 基本法に基づき 2010 年 12 月にバイオマス活用推進基本計 画が策定されている (2016 年 9 月に改定)。また, 2011 年 3 月に発生した東日本大震災を契機に, 再生可能エネルギー 電気の導入推進を目的として，2012 年 7 月に固定価格買取 制度が施行され, 発電のエネルギー源としての利用が拡大し ている。

エネルギー源として利用可能なバイオマスは，大きく分け て廃棄物系, 未利用系, 生産系に分類される。バイオマス をエネルギー利用する際，特に廃棄物系バイオマスの畜産廃 棄物や家庭ごみ，污泥等については，水分や臭気の問題で そのままの形態で利用するのが困難な場合があり，その対 策の一つとして炭化処理が行われる。バイオマスから製造さ れた炭化物（以下，バイオマス炭化物）は，石炭に類似した 性状を示すことから，石炭代替燃料としての利用が可能であ るが, 石炭同様, 空気䨌囲気下で酸化反応を起こすため, 発熱特性を十分に把握した上で取り扱うことが重要である。

石炭の自己発熱性に影響を与える因子としては，外的環境 によるものと石炭の性状によるものがある。前者は，石炭の 貯留時に扔ける堆積量, 期間, 温度, 空気の流通等があり, 後者は, 石炭の可燃分組成, 揮発分, 灰分, 含水率, 粒径, 表面積等が挙げられる。石炭の性状による影響については既 往の研究において数多〈の報告がなされている。Wang ら 1)2) が報告するには, 石炭の酸化には二つの反応経路が存在し, 一つは石炭が酸化されて $\mathrm{CO}_{2}$ や $\mathrm{CO}$ といったガスを迅速に生 成する反応で，もう一つは酸素の化学吸着である。化学吸 着の反応過程では，まず石炭に酸素が吸着され過酸化物を 生成し，ヒドロキシル基，カルボニル基，カルボキシル基を 経て，新たな活性サイトが生み出され，酸素の吸着が繰り返 されるとしている。

これらの反応は, 水や無機物の存在により反応速度が変
化することが知られている。Clemens ら ${ }^{3)}$ は，石炭表面に 水が存在すると, 水がない場合と比較してラジカルが安定し て存在できるようになり, その結果, 酸化反応が促進する が, 含水率が高くなり水の層が厚くなると, 酸素の拡散が阻 害され酸化反応が抑制されると報告している。また，Zhang ら 4） 5) は，オーストラリア産の褐炭と金属塩を用いて，無 機物が酸化反応に与える影響を評価しており, 炭酸カルシ ウム $\left(\mathrm{CaCO}_{3}\right)$, 酢酸ナトリウム $\left(\mathrm{CH}_{3} \mathrm{COONa}\right)$, 酢酸カリウム $\left(\mathrm{CH}_{3} \mathrm{COOK}\right)$ ，黄鉄鉱 $\left(\mathrm{FeS}_{2}\right)$ を混合した場合に酸化速度が 促進され，塩化ナトリウム $(\mathrm{NaCl})$, 塩化カリウム $(\mathrm{KCl})$ を 混合した際に酸化速度が抑制されると報告している。

廃棄物系のバイオマスには, 天然由来の無機物の他, 人 間活動に伴って排出される化合物や, バイオマスの中間処理 工程の中で添加される人工的な化合物が含まれる。特に, 含水率が高いものまたは臭気が強いバイオマスでは, 脱水 性向上や臭気抑制等を目的として, 多量の鉄化合物を添加 する場合がある。著者の経験から，鉄化合物を含む原料を 炭化処理すると自己発熱性が増す傾向があるが，既往の研 究において, 廃棄物系のバイオマスを原料とする炭化物の自 己発熱性について報告された事例はない。そこで本研究で は，鉄化合物による自己発熱性への影響を評価するため, 鉄化合物の形態解析と酸化反応による発熱挙動について確 認を行ったので，その結果について報告する。

\section{2. 実験方法}

\section{1 鉄化合物の分析}

\subsection{1 分析方法}

鉄化合物の分析は, XAFS(X-ray Absorption fine structure: $\mathrm{X}$ 線吸収微細構造）とXRD（X線回折，（株）リガク製 SmartLab SE）を用いた。XAFSは, 測定対象の結晶性や 有機物の含有に関係なく測定可能という利点を有するが, 測 定可能な施設が限られており時間的な制約もあることから， 鉄化合物の含有量が多い場合はXRDによる測定を行った。

XAFS の測定は, 大型放射光施設である SPring-8 (ビー ムライン BL14B2）を利用し，透過法にて行った。XAFS 測 定の概要を Fig. 1 に示す。吸収係数 $\mu$ は以下の式で算出さ れる。

$$
\mu \mathrm{t}=-\ln \left(\mathrm{I} / \mathrm{I}_{0}\right)
$$

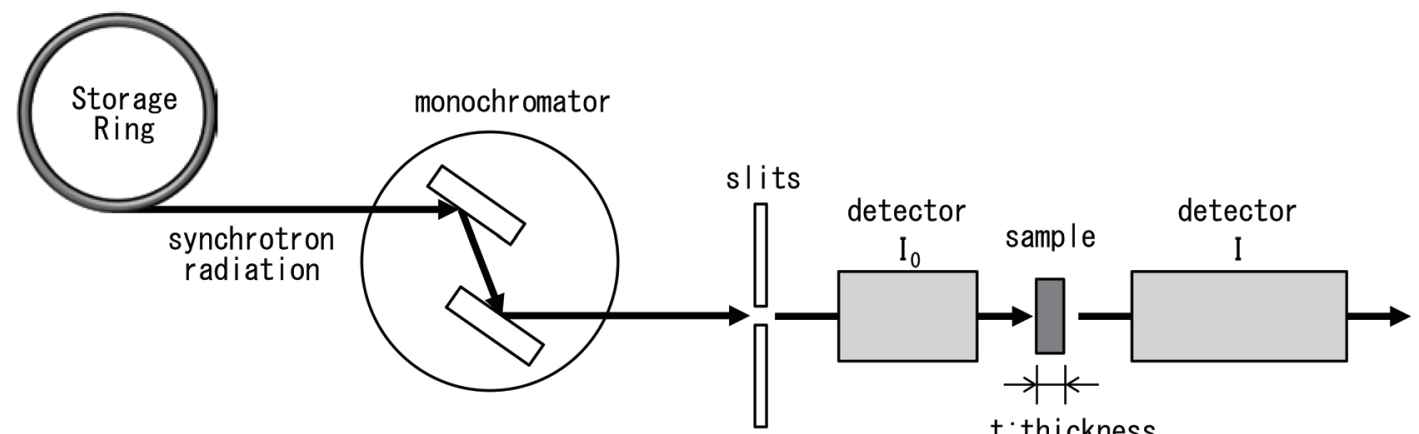

Fig. 1 Outline of XAFS method 
$\mathrm{t}$ は試料の厚さ, $\mathrm{I}_{0}$ は $\mathrm{Si}$ (111) モノクロメーターで単色化され た入射 X 線の強度, I は透過 X 線の強度である。XAFS で 得られたスペクトルは，(株）リガク製ソフトウェア REX2000 を用いて解析を行い, バックグランド（空気により散乱したス ペクトル）を差し引いた後，大きな振動構造が観察されなく なった 7,400 $\mathrm{eV}$ 付近で $\mu \mathrm{t}=1$ となるように規格化を行った ${ }^{6)}$ 。

\section{1 .2 試料の製造条件}

バイオマスに人工的に添加された鉄化合物が炭化処理に よりどのような形態になるか確認するため, 添加する薬剤と してポリ硫酸第二鉄を選定し，各種試料を製造した。なお， ポリ硫酸第二鉄 (poly ferric sulfate $(\mathrm{PFS}))$ は $\left[\mathrm{Fe}_{2}(\mathrm{OH})_{\mathrm{n}}\right.$ $\left.\left(\mathrm{SO}_{4}\right)_{3-\mathrm{n} / 2}\right]_{\mathrm{m}}$ の化学式で示される化合物で, $\mathrm{H}_{2} \mathrm{~S}$ の抑制やバイ オマスの脱水助剂等として広く利用されている薬剤である。 薬剤として流通しているものは水溶液であり, 主成分の $\mathrm{Fe}$ と $\mathrm{SO}_{4}{ }^{2-の}$ の合計が質量分率の約 4 割を占める。製造メーカが 公表している組成例 (溶液中の質量分率) を Table 1 に示す。 以下の実験でポリ硫酸第二鉄を使用する場合は，希橎や濃 縮を行わず原液のまま使用した。

(1) ポリ硫酸第二鉄単独試料

ポリ硫酸第二鉄の形態変化を確認するため, ポリ硫酸第 二鉄単独で炭化と同様の処理（窒素雲囲気下での熱処理） を行い, XAFS 測定を行った。熱処理の方法は以下に示す とおりである。

まず，ポリ硫酸第二鉄溶液を乾燥して乾燥物を製造し， 次に, Fig. 2 に示すように石英ガラス管の中央部に試料を保 持し，窒素ガスを流通しながら，試料直近に配した温度計 が所定の温度となるよう電気ヒーターで加熱した。熱処理時 間は商用プラントと条件を合わせるため 1 時間とし，熱処理 温度は, $250^{\circ} \mathrm{C}, 350^{\circ} \mathrm{C}, 500^{\circ} \mathrm{C}$ の 3 条件とした。

Table 1 Composition of poly ferric sulfate (PFS) aqueous solution

\begin{tabular}{ccc}
\hline item & unit & value \\
\hline specific gravity $\left(20^{\circ} \mathrm{C}\right)$ & - & 1.457 \\
$\mathrm{pH}$ & - & 2.2 \\
$\mathrm{~T}-\mathrm{Fe}$ & $\%$ & 11.3 \\
$\mathrm{Fe}^{2+}$ & $\%$ & $<0.01$ \\
$\mathrm{SO}_{4}{ }^{2-}$ & $\%$ & 26.9 \\
$\mathrm{Cl}^{-}$ & $\%$ & $<0.01$ \\
\hline
\end{tabular}

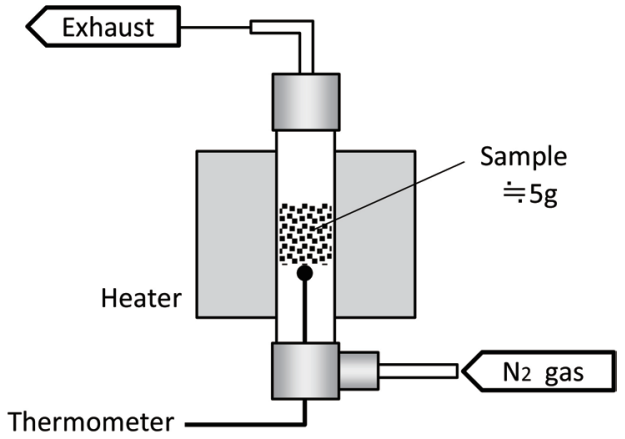

Fig. 2 Carbonization equipment in laboratory
(2) ポリ硫酸第二鉄とセルロースの混合試料

ポリ硫酸第二鉄の形態変化について，有機物の存在によ る影響を確認するため, ポリ硫酸第二鉄とバイオマスの構成 成分の一つであるセルロースを混合した模擬サンプルを製造 した。炭化物を製造するにあたり, セルロースは混合性や拡 散性を考慮し，パウダー状のものを使用した。セルロースパ ウダーとポリ硫酸第二鉄の混合比は，Fe，C，H の含有量が, ポリ硫酸第二鉄由来の鉄化合物を含むバイオマス原料から 炭化物を製造する商用プラントの乾燥原料とほぼ同等となる ようセルロースパウダー $9.8 \mathrm{~g}$ (dry) とポリ硫酸第二鉄水溶 液 $10.8 \mathrm{~g}$ を混合した。乾燥原料と模擬サンプルの組成（質 量分率）を Table 2 に示す。

模擬サンプルの製造は，まず，セルロースパウダーとポリ 硫酸第二鉄の混合物を乾燥した後, 2.1 .2 (1) に示した方法 と同様の手順にて炭化処理した。

(3) 商用プラント採取試料

ポリ硫酸第二鉄由来の鉄化合物を含むバイオマス原料か ら炭化物を製造する商用プラントにおいて，各プロセスから 以下に示す試料を採取し，そのうち，(2)～(4)の試料を対象 としてXAFS 測定を行った。

(1)バイオマス原料：商用プラントの入口の処理対象物

(2)乾燥原料：バイオマス原料を乾燥したもの

(3)炭化物：乾燥原料を炭化したもの

(4)酸化後炭化物：炭化物を空気雲囲気下で数日間保持し たもの

この商用プラントでは，まず，バイオマス原料を熱風乾燥機 により水分 $20 \sim 30 \%$ 程度まで乾燥し, 外熱キルン型の炭化 炉にて $300 \sim 350^{\circ} \mathrm{C}$ 程度の温度で約 1 時間かけて炭化する。 製造された炭化物は, 数日間空気雾囲気下に保持された後, 燃料化物として出荷される。

(4) ポリ硫酸第二鉄と商用プラントのバイオマス原料の混合 試料

バイオマス原料にポリ硫酸第二鉄を添加し炭化物を製造 した際の鉄化合物の形態を明確にするため，ポリ硫酸第二

Table 2 Composition of dried biomass and simulated sample

\begin{tabular}{|c|c|c|c|}
\hline & & Dried biomass & Simulated sample \\
\hline moisture & $\%$ & 17.8 & - \\
\hline ash & dry\% & 36.6 & - \\
\hline $\mathrm{C}$ & dry\% & 32.2 & 27.8 \\
\hline $\mathrm{H}$ & dry\% & 5.0 & 5.5 \\
\hline $\mathrm{N}$ & dry\% & 4.3 & $<0.1$ \\
\hline S & dry\% & 1.8 & 6.2 \\
\hline $\mathrm{O}$ & dry\% & 20.0 & 53.3 \\
\hline $\mathrm{Fe}$ & dry\% & 7.0 & 7.3 \\
\hline $\mathrm{Mg}$ & dry\% & 0.49 & - \\
\hline $\mathrm{Al}$ & dry\% & 1.8 & - \\
\hline $\mathrm{Si}$ & dry\% & 2.8 & - \\
\hline $\mathrm{P}$ & dry\% & 2.1 & - \\
\hline $\mathrm{Ca}$ & dry\% & 1.9 & - \\
\hline other & dry\% & 20.4 & - \\
\hline
\end{tabular}


Table 3 Composition of dried biomass mixed with PFS

\begin{tabular}{lcccccccc}
\hline & & $\mathrm{C}$ & $\mathrm{H}$ & $\mathrm{N}$ & $\mathrm{O}$ & $\mathrm{Fe}$ & $\mathrm{S}$ & other \\
\hline Dried biomass & $\mathrm{dry} \%$ & 28.1 & 4.6 & 3.7 & 18.1 & 4.0 & 1.5 & 40.0 \\
\hline Dried biomass mixed with PFS & $\mathrm{dry} \%$ & 9.9 & 1.6 & 1.3 & 36.8 & 20.6 & 15.8 & 14.0 \\
\hline
\end{tabular}

Table 4 Composition of biomass added PFS

\begin{tabular}{lcccccccc}
\hline & & $\mathrm{C}$ & $\mathrm{H}$ & $\mathrm{N}$ & $\mathrm{O}$ & $\mathrm{Fe}$ & $\mathrm{S}$ & other \\
\hline no PFS & dry\% & 49.1 & 4.6 & 7.1 & 11.1 & 1.8 & 0.9 & 25.4 \\
\hline add PFS & dry\% & 45.3 & 4.3 & 6.6 & 11.1 & 4.6 & 1.1 & 27.1 \\
\hline add more PFS & dry\% & 41.1 & 4.0 & 6.1 & 11.6 & 8.6 & 1.5 & 27.1 \\
\hline
\end{tabular}

鉄を過剩に添加した試料を製造した。混合比は，バイオマ ス原料の $\mathrm{CHO}$ の合計に対して，ポリ硫酸第二鉄の $\mathrm{Fe}$ が重 量比でほぼ同量となるようバイオマス原料 $7.6 \mathrm{~g}$ (dry) とポ リ硫酸第二鉄溶液 $36.7 \mathrm{~g}$ を混合した。ポリ硫酸第二鉄混合 前後の組成を Table 3 に示す。

炭化物の製造は，まず，商用プラントから採取したバイオ マス原料にポリ硫酸第二鉄を混合し，乾燥を行った後，2.1.2 （1）に示した方法と同様の手順にて炭化処理した。また，得 られた炭化物を空気雾囲気において $105^{\circ} \mathrm{C} て ゙ 24$ 時間保持し 酸化させた試料も製造した。

\subsection{3 試料の前処理・保管条件}

今回測定対象とした試料は，空気雲囲気下において酸化 反応により鉄化合物の形態が変化するため 7) 8)，試料の前処 理や保管条件は次のとおりとした。

$\mathrm{XAFS}$ 測定では，試料の密度や厚さの違いによるX 線の 吸収への影響を避けるため，前処理として錠剤成型を行う。 また，適切な吸収スペクトルを得るためには，対象元素の 濃度が一定範囲内にある必要があるため, 濃度が高い場合 は窒化ホウ素を用いて希釈する。試料と窒化ホウ素をメノウ 乳鉢に入れて，粉砕しながら十分に混合する操作を行った 後，油圧プレスで錠剤状に成型した。これら前処理操作は 全てアルゴンガス雲囲気に保持したグローブボックス内で行 い, 成型後の試料は, セラミック蒸着樹脂製の袋でシールし, 測定まで酸素が透過しない状態で保管した。また，商用プ ラントや実験装置から炭化物を採取する場合には，試料を 採取後速やかに大量の脱酸素剂を入れたセラミック蒸着樹 脂製の袋に入れ，常温にて酸素を遮断した状態で保管した。 また，保管期間中の酸素の遮断状態を確認するため，試料 と共に酸素検知剂を同梱した。

\section{2 鉄化合物の発熱挙動}

\section{2 .1 分析方法}

試料の酸化反応による発熱挙動は TG/DTA（示差熱分 析，ネッチ・ジャパン(株) 製 STA2500）を用いて測定した。 TG/DTAの測定では，試料に残存する水分の影響を排除す るため，試料を測定装置にセットした後，窒素雲囲気下で 所定の温度 $\left(90^{\circ} \mathrm{C}\right)$ まで昇温し，重量が恒量となるまで乾燥 を行った。次に, $90^{\circ} \mathrm{C}$ 一定のまま窒素䨌囲気から空気䨌囲 気に切り替えて DTAの測定值が一定となるまで温度を保持
し(約 120 分), 発熱の挙動を確認した。

\section{2 .2 試料の製造条件}

(1) 商用プラント炭化物

原料中にポリ硫酸第二鉄由来の鉄化合物を含む商用プラ ントにおいて, 製造直後の炭化物（炭化温度約 $300^{\circ} \mathrm{C}$ ） と, その炭化物を数日間空気雲囲気下に保持して酸化させた炭 化物を採取し，TG/DTAによる測定を行った。

（2）ポリ硫酸第二鉄由来の鉄化合物の発熱挙動

酸化反応により発生する熱量は，鉄化合物の酸化反応に よるものの他，官能基の酸化反応による熱量等が含まれる。 そこで, 鉄化合物単独の発熱挙動を確認するため, ポリ硫 酸第二鉄を含まないバイオマス原料を用意し，そこにポリ硫 酸第二鉄を添加してTG/DTAによる測定を行った。ポリ硫 酸第二鉄の添加量は, バイオマス原料 $50.4 \mathrm{~g}$ （dry）に対し, $9.2 \mathrm{~g}$ と $22.9 \mathrm{~g}$ の 2 条件とした。添加後の組成を Table 4 に 示す。炭化物の製造条件は 2.1.2(1) 項に示す方法とした(炭 化温度約 $300^{\circ} \mathrm{C}$ )。

\section{2 .3 試料の前処理・保管条件}

2.1 .3 項に示した方法と同様とした。

\section{3. 実験結果・考察}

3.1 鉄化合物の形態について

(1) ポリ硫酸第二鉄単独

ポリ硫酸第二鉄単独による乾燥物, 熱処理物（熱処理温 度 $\left.250^{\circ} \mathrm{C}, 350^{\circ} \mathrm{C}, 500^{\circ} \mathrm{C}\right)$ の XAFS 測定結果を Fig. 3 に示 す。Fig. 3 では X 線吸収端近傍のエネルギー領域のスペクト ル（XANES）を示している。乾燥物, 熱処理物ともにスペ クトルがほぼ重なっており, ポリ硫酸第二鉄単独での乾燥お よび熱処理では，鉄化合物の結晶構造の変化は認められな かった。図示はしないが, XRD 分析の結果, 化学組成とし ては $\mathrm{Fe}_{2}\left(\mathrm{SO}_{4}\right)_{3}$ の形態で存在していることが確認された。

(2) ポリ硫酸第二鉄とセルロースパウダーの混合物

ポリ硫酸第二鉄とセルロースパウダーの混合物である模擬 サンプルの乾燥物および炭化物（炭化温度 $250^{\circ} \mathrm{C}, 350^{\circ} \mathrm{C}$, $500^{\circ} \mathrm{C}$ ）のXAFS 測定結果を Fig. 4 に示す。模擬サンプル乾 燥物のスペクトルは，ポリ硫酸第二鉄単独の乾燥物とほぼ同 じであり，鉄化合物の変化はないと考元られる。つまり，乾 燥操作に扔いては，有機物の存在有無により，ポリ硫酸第 二鉄由来の鉄化合物の形態が変化しないことを示している。 


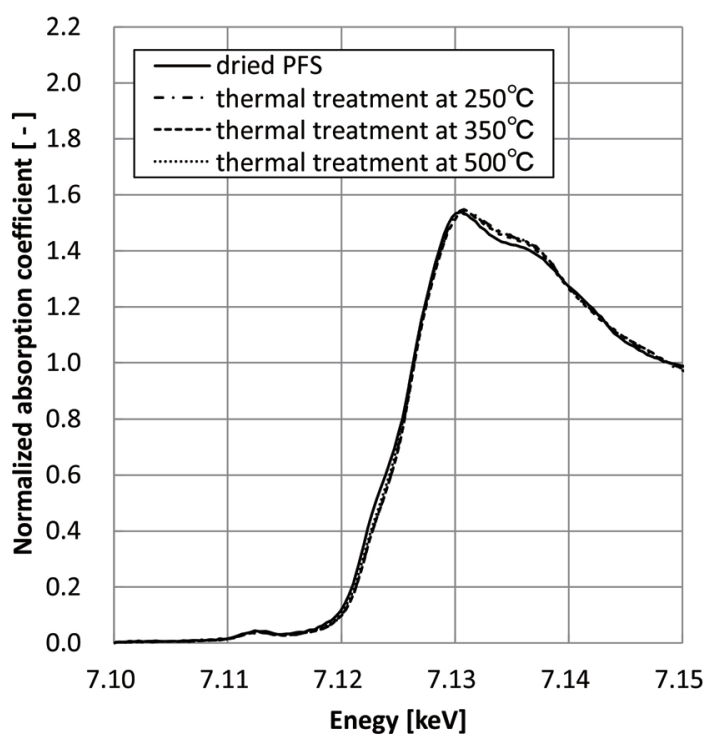

Fig. 3 XANES spectrum of dried and carbonized PFS

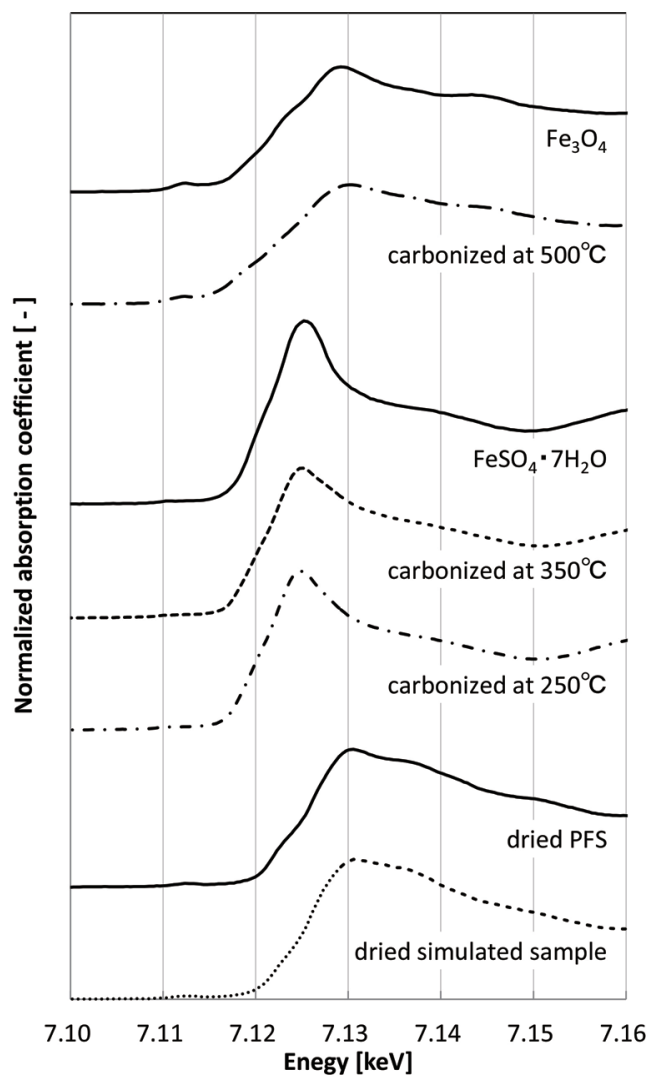

Fig. 4 XANES spectrum of simulated sample mixed with PFS and cellulose

一方, $250^{\circ} \mathrm{C}$ 炭化物と $350^{\circ} \mathrm{C}$ 炭化物のスペクトルは, $\mathrm{FeSO}_{4}$. $7 \mathrm{H}_{2} \mathrm{O}$ のスペクトルと形状が近い。また， $500^{\circ} \mathrm{C}$ 炭化物につい ては $\mathrm{Fe}_{3} \mathrm{O}_{4}$ のスペクトルと形状が近い。

以上の結果から，七ルロースパウダーとポリ硫酸第二鉄の 混合物における鉄化合物は三価の $\mathrm{Fe}_{2}\left(\mathrm{SO}_{4}\right)_{3}$ の形態で存在 し， $250 \sim 350^{\circ} \mathrm{C}$ 程度で炭化処理することにより還元が進み 二価の $\mathrm{FeSO}_{4} \cdot 7 \mathrm{H}_{2} \mathrm{O}$ となり, さらに $500^{\circ} \mathrm{C}$ まで炭化温度を
上げると二価と三価のスピネル構造を持つ $\mathrm{Fe}_{3} \mathrm{O}_{4}$ になること が示唆された。

(3) 商用プラント採取試料

商用プラントの各種試料について鉄化合物の形態を確認 するため,まずは標準試料として Fe, FeS, FeS, $\mathrm{FeO}$, $\mathrm{Fe}_{2} \mathrm{O}_{3}, \mathrm{Fe}_{3} \mathrm{O}_{4}, \alpha-\mathrm{FeOOH}, \boldsymbol{\gamma}-\mathrm{FeOOH}, \mathrm{Fe}_{2} \mathrm{SiO}_{4}, \mathrm{FeCl}_{3}$, $\mathrm{FeSO}_{4} \cdot 7 \mathrm{H}_{2} \mathrm{O}$ についてXAFS 測定を行った。これらのう ち, $\mathrm{Fe}, \mathrm{FeO}, \mathrm{Fe}_{2} \mathrm{O}_{3}, \mathrm{Fe}_{3} \mathrm{O}_{4}, \mathrm{FeSO}_{4} \cdot 7 \mathrm{H}_{2} \mathrm{O}$ の測定結果を Fig. 5 に示す。

次に, 乾燥原料, 炭化物, 酸化後炭化物について, XAFS 測定の結果を Fig. 6 に示す。標準試料（Fig. 5 に示し た以外の標準試料も含む）のスペクトルと比較したが，いず れの鉄化合物とも近似できなかった。原因として, Feが特

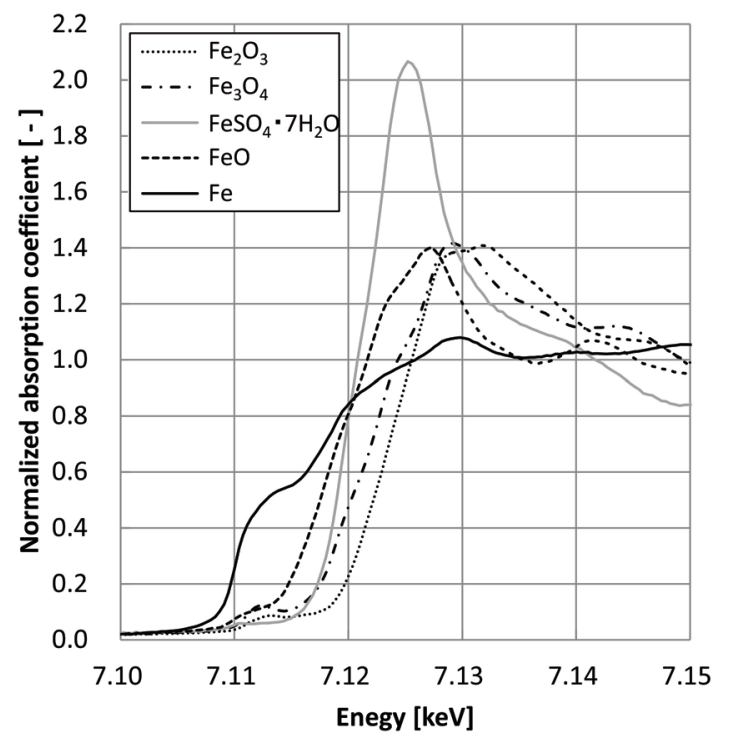

Fig. 5 XANES spectrum of standard samples of iron compounds

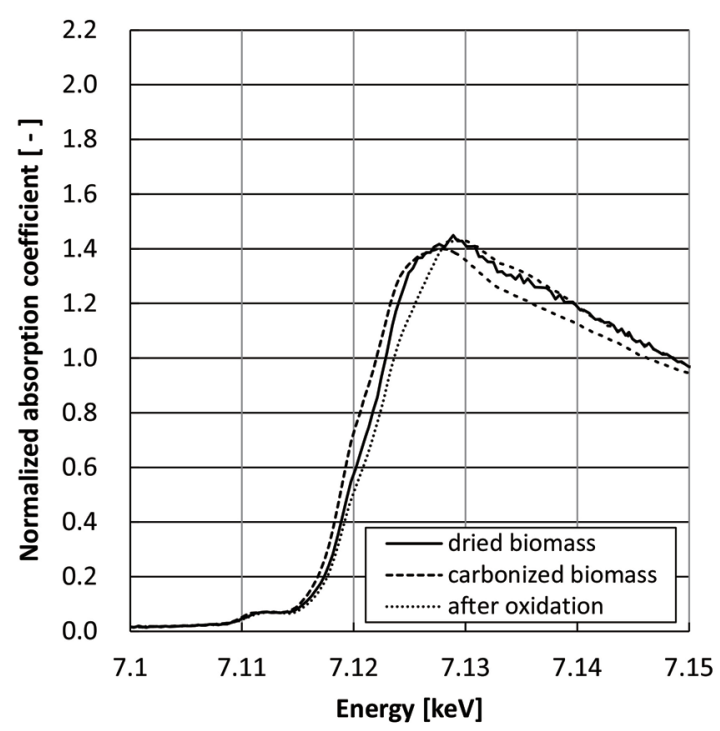

Fig. 6 XANES spectrum of dried biomass, carbonized biomass and carbonized biomass after oxidation 
定の化合物で在していないことが考えられる。さらに, Fe に近接する元素が多数存在するため, 標準試料のスペクトル に近似したスペクトルを示さないと推察される。

一方, $\mathrm{Fe}$ の価数とスペクトルの挙動については一定の傾 向が認められる。Fig. 5 において，Feが最も低エネルギー 側に位置し，価数の増加と共に高エネルギー側にシフトして いる $\left(\mathrm{FeO}, \mathrm{FeSO}_{4} \cdot 7 \mathrm{H}_{2} \mathrm{O}\right.$ は 2 価, $\mathrm{Fe}_{3} \mathrm{O}_{4}$ は2 価と 3 価の混合, $\mathrm{Fe}_{2} \mathrm{O}_{3}$ は 3 価)。これは，XAFS 測定において，スペクトルの 挙動を確認することにより，Feの価数の挙動を推定できるこ とを示している。Fig. 6 に示すように，炭化物のスペクトルは 乾燥原料に対して低エネルギー側にシフトした。これは，乾 燥原料が炭化処理される際, 希薄酸素雲囲気下で加熱処理 されるため還元反応が進行し，価数の小さな鉄化合物が生 成されたためと考えられる。したがって，炭化物は乾燥原料 と比較して酸化反応を生じやすく，自己発熱性が増している と言える。一方，酸化後炭化物のスペクトルは高エネルギー 側にシフトした。これは，炭化物が空気雲囲気下で数日間 保持される間に酸化が進行し，価数の大きな鉄化合物へ変 化したためと考えられる。したがって, 酸化後炭化物は炭化 物や乾燥原料と比較して酸化反応を生じにくく, 自己発熱性 が抑制されていると言える。

なお，Fig. 5 と Fig. 6 のデー夕は筆者らが SPring-8 利用 研究成果集 7) 8)に記載した内容を再編集したものである。

(4) ポリ硫酸第二鉄と商用プラントのバイオマス原料の混合 試料

商用プラントのバイオマス原料にポリ硫酸第二鉄を過㮃に 添加した試料について, 酸化前と酸化後の炭化物の XRD 分 析の結果をそれぞれ Fig. 7 と Fig. 8 に示す。この結果より, バイオマスに混合されたポリ硫酸第二鉄は炭化処理により $\mathrm{FeSO}_{4} \cdot \mathrm{xH}_{2} \mathrm{O} （ \mathrm{x}=1,4,7 ）$ となり，この炭化物を酸化させる ことにより， $\mathrm{Fe}(\mathrm{OH}) \mathrm{SO}_{4}$ となることが確認された。

(2)，(4)の結果から，バイオマス原料に添加されたポリ 硫酸第二鉄は Fig. 9 に示すような挙動を示すことが確認され た。

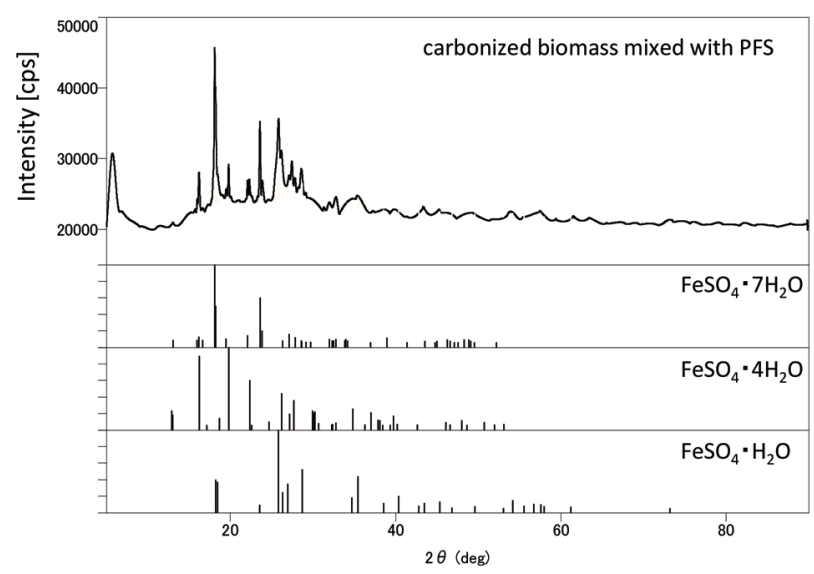

Fig. 7 Iron compounds in carbonized biomass mixed with PFS

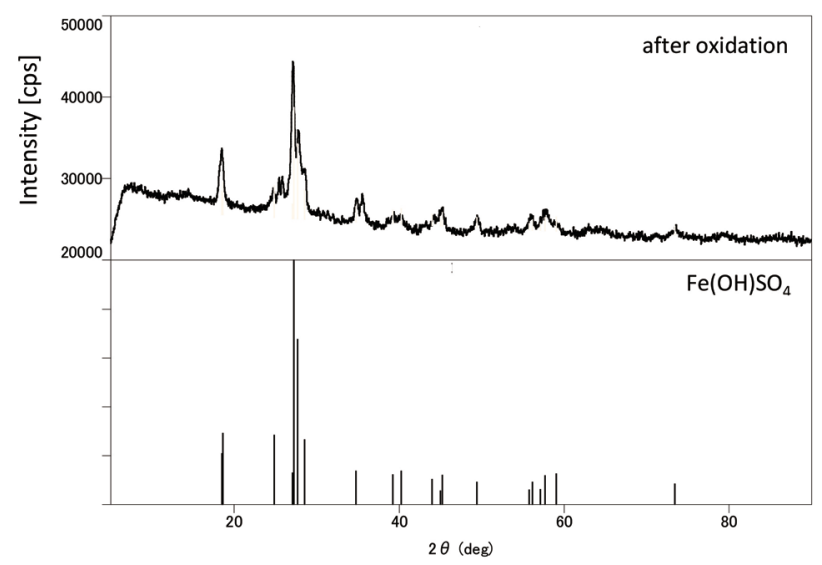

Fig. 8 Iron compounds in carbonized biomass mixed with PFS after oxidation

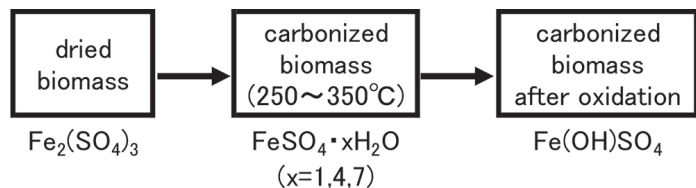

Fig. 9 Behavior of iron compounds in carbonized biomass mixed with PFS

\section{2 鉄化合物の発熱挙動について}

（1）商用プラント炭化物の発熱挙動

原料中にポリ硫酸第二鉄由来の鉄化合物を含む商用プラ ントから採取した炭化物の TG/DTA 測定結果をFig. 10 に 示す。製造直後の炭化物は, 空気雲囲気に切替えた直後に DTA の明確なピークが認められ，発熱反応を生じる化合物 が含有していることが示された。一方, 酸化後炭化物は, ピー クは認められるが明らかに小さくなっており，酸化反応が進 行していたことが裏付けられた。測定中の発生熱量に比例す ると考えられるDTA ピーク面積（試料単位重量あたり）で 比較すると，酸化後炭化物は酸化前の $10 \%$ 以下となってい た。

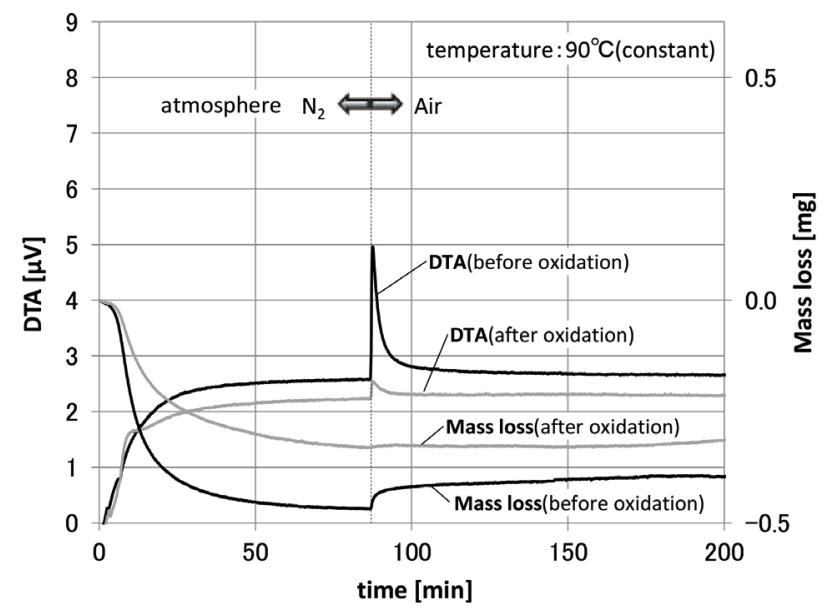

Fig. 10 TG/DTA results of carbonized biomass before and after oxidation 


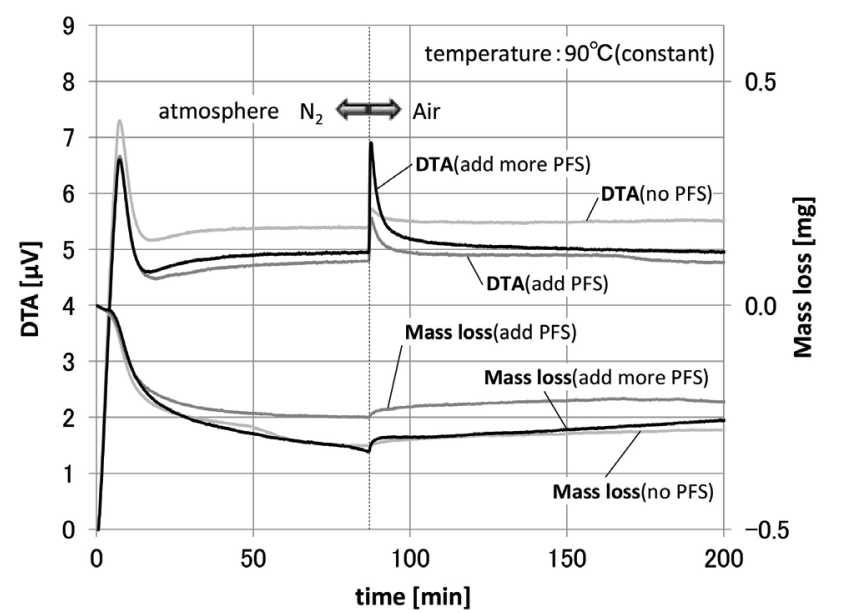

Fig. 11 Influence of amount of PFS to TG/DTA results

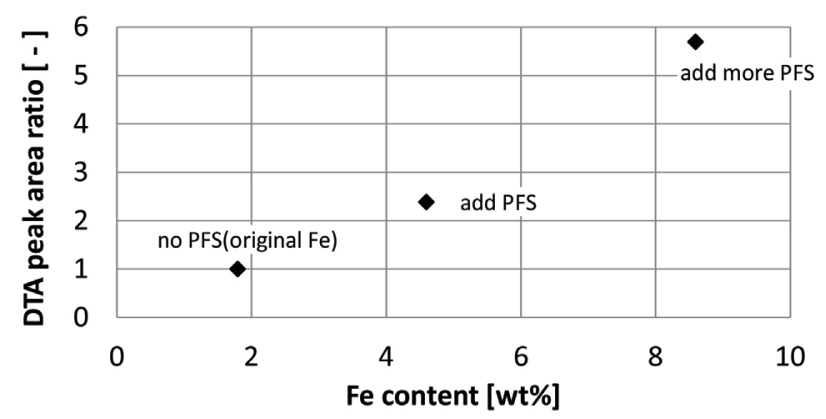

Fig. 12 Relationship between Fe content and DTA peak area

\section{（2）ポリ硫酸第二鉄由来の鉄化合物の発熱挙動}

ポリ硫酸第二鉄を含まないバイオマス原料にポリ硫酸 第二鉄を添加して製造した炭化物の TG/DTA 測定結果を Fig. 11 に示す。また，炭化物中の Fe 含有率と DTA ピーク 面積の関係を Fig. 12 に示す。DTA ピーク面積は, PFS 添 加無しの場合の面積を 1 として相対的に示した。Fe含有率 と DTA ピーク面積には正の相関が認められ, ポリ硫酸第二 鉄由来の鉄化合物が発熱に寄与していることが裏付けられ た。この発熱反応は, 前述した鉄化合物の形態解析より, $\mathrm{FeSO}_{4}$ の水和物が $\mathrm{Fe}(\mathrm{OH}) \mathrm{SO}_{4}$ に酸化される反応に基づくも のと考えられる。TG/DTAでは発熱量の絶対値を正確に測 定できないため, 今後, 他の測定法により発熱量を測定して いきたい。

\section{4. 結 言}

廃棄物系のバイオマスを原料とする炭化物について，ポリ 硫酸第二鉄由来の鉄化合物の形態解析及び酸化反応による 発熱挙動について確認を行った。

(1) ポリ硫酸第二鉄由来の鉄化合物を含むバイオマス原料か ら炭化物を製造する際, 炭化物を空気雲囲気下で数日間 保持して酸化を進行させることにより，もとのバイオマス 原料よりも自己発熱性を抑制できる可能性があることが 示唆された。

(2) ポリ硫酸第二鉄単独での乾燥および炭化処理では, 鉄 化合物の結晶構造や価数の変化は認められないが, 有 機物の存在下では還元反応が進み, $\mathrm{FeSO}_{4} \cdot \mathrm{xH}_{2} \mathrm{O}$ $(\mathrm{x}=1,4,7)$ が生成される。これらの鉄化合物は, 空気 雲囲気下に保持すると, 酸化反応により $\mathrm{Fe}(\mathrm{OH}) \mathrm{SO}_{4}$ とな ることが確認された。

(3) ポリ硫酸第二鉄の添加量に応じて炭化物の酸化反応によ る発熱量が変化したことから，ポリ硫酸第二鉄由来の鉄 化合物が発熱に寄与していることが裏付けられた。今後, 発熱量の絶対值を正確に測定していきたい。

\section{文 献：References}

1) Wang, H.; Dlugogorski, B. Z.; Kennedy, E. M., Combustion and Flame, 134, 107-117 (2003)

2) Wang, H.; Dlugogorski, B. Z.; Kennedy, E. M., Progress in Energy and Combustion Science, 29, 487-513 (2003)

3) Clemens, A. H.; Matheson, T. W., Fuel, 75, 891-895 (1996)

4) Zhang, D. K.; Sujanti, W., Fuel, 78, 549-556 (1999)

5) Watanabe, W. S.; Zhang, D. K., Fuel Processing Technology, 74, 145-160 (2001)

6) Ota, T., Xsen Kyuusyuubunkouhou - XAFS to sono ouyou -, IPC, p. 59 (2002): 太田俊明, X 線吸収分光法 -XAFS とその応用 -, アイピーシー, p. 59 (2002)

7) Hira, S.; Ueda, A.; Suzuki, K.; Takeda, R.; Numako, C., SPring-8 riyou kenkyuu seikasyuu, 5, 105 (2017):日良聡, 上田厚志, 鈴木健治, 武田龍二, 沼子千弥, SPring- 8 利 用研究成果集, 5, 105 (2017)

8) Hira, S.; Ueda, A.; Suzuki, K.; Takeda, R.; Numako, C., SPring-8 riyou kenkyuu seikasyuu, 6, 109 (2018):日良聡, 上田厚志, 鈴木健治, 武田龍二, 沼子千弥, SPring- 8 利 用研究成果集, 6, 109 (2018) 